\title{
From good practice for good practice we theorize; in small words for big circles we write
}

\author{
Wei-Ning Xiang ${ }^{1}$
}

Received: 24 January 2020 / Accepted: 28 January 2020 / Published online: 17 February 2020

(c) Springer Nature Singapore Pte Ltd. 2020

\begin{abstract}
As members of the socio-ecological practice research community, how should we theorize so that our theories of socioecological practice are both true and useful? How should we write so that our articles will be read and admired by a broad audience? In this perspective essay, I advocate a theorizing approach and a writing strategy through classic examples of two legendary scholars.
\end{abstract}

Keywords Socio-ecological practice $\cdot$ Socio-ecological practice research $\cdot$ Theory of practice $\cdot$ Ecopracticology $\cdot$ Aristotle $\cdot$ Nicomachean Ethics · Adam Smith · The Wealth of Nations · Perspicuity

\section{How should we theorize and write?}

As members of the socio-ecological practice research (SEPR) community, we are committed to the mission of cultivating and celebrating topnotch scholarship in Ecopracticology - the study of socio-ecological practice (Xiang 2019a, p. 4, b). We are as such committed to both developing theories of socio-ecological practice that are true and useful to the people we are privileged to serve-socio-ecological practitioners, scholar-practitioners, and fellow scholars (Xiang 2019b, pp. 7-9), and writing articles that, beside ourselves, others will also read and admire (Xiang 2019a, p. 4). But how should we theorize and write to fulfill these commitments? My response is terse: theorize from good practice for good practice; write in small words for big circles. It is inspired by two legendary scholars and examples of their topnotch scholarship.

Wei-Ning Xiang

wxiang@uncc.edu

1 The University of North Carolina at Charlotte, Charlotte, $\mathrm{NC}$, USA

\section{An example of Aristotelian theorizing: from good practice for good practice}

Two thousand four hundred years ago on the Isle of Lesbos in Greece, Greek philosopher Aristotle (384-322 B.C.) spent time observing how the local masons improvised in measuring the circumference of stone columns. This, according to American scholars Barry Schwartz and Kenneth Sharpe, is in fact part of his fieldwork on the construct of phronesis (practical wisdom).

About this instance of Aristotelian theorizing, write Barry Schwartz and Kenneth Sharpe in their 2010 book Practical Wisdom: The Right Way to Do the Right Thing (Schwartz and Sharpe 2010, pp. 28-29; italics and parentheses by the author):

Aristotle was particularly fascinated with how the masons on the Isle of Lesbos used rulers. A normal, straight-edged ruler was of little use to the masons who were carving round columns from slabs of stone and needed to measure the circumference of the columns. Unless you bent the ruler. Which is exactly what the masons did. They fashioned a flexible ruler out of lead, a forerunner of today's tape measure. For Aristotle, knowing how to bend the rule to fit the circumstance was exactly what practical wisdom (phronesis) was all about. ... [T] $]$ he masons of Lesbos didn't bend the rule to cheat or deceive. They bent the rule to do what was right, and to do it well. 
Aristotle also spent time in Athens, Greece, watching how the blacksmiths, boat pilots, carpenters, and shoemakers improvised in their work (Schwartz and Sharpe 2010, p. 28). Like the masons on the Isle of Lesbos, these craftsmen too must improvise because neither was their work "governed by systematically applying rules or following rigid procedures. The materials they worked with were too irregular, and each task posed new problems." (Ibid.) ${ }^{1}$

From these observations, Aristotle discerned that the ways the craftsmen improvised in their practices illuminate what phronesis is, how it differs from and relates to the other virtue sophia (theoretical wisdom). ${ }^{2}$ And more importantly, "Aristotle thought the choices craftsmen made in acting on the material world provided clues to the kind of know-how citizens needed to make moral choices in the social world" (Schwartz and Sharpe 2010, p. 28, italic by the author). Later in Nicomachean Ethics (book V, chapter 10), he used what he observed and discerned from the stone-cutting practice of the masons, known later as Aristotle's Lesbian rule, ${ }^{3}$ to illuminate the social practice of fair justice (DeCoursey 2011, p. 293; James 2016, p. 19). In making the argument that to be fair, rules or standards should be adaptable to specific circumstances, he offered an eloquent simile (Aristotle 1999, p. 84; parenthesis by the author):

For the standard applied to the indefinite is itself indefinite, as the lead standard is in Lesbian building, where it is not fixed, but adapts itself to the shape of the stone; similarly, a (judicial) decree is adapted to fit its objects.

\footnotetext{
1 Many contemporary scholars also recognized the importance of improvisation to social practice. These include, but are not limited to, American planning scholar John Forester (1999, pp. 224-241, 2019), Chinese philosopher Mao Zedong (previously translated as Mao TseTung) (1937), American philosopher Martha Nussbaum (1990, pp. 94, 96-97), and Chinese-American geographer and planning scholar Wei-Ning Xiang $(2016,2019 \mathrm{c})$. Most noteworthy is an aphorism by John Forester that "academics can theorize, but practitioners must improvise" (Forester 1999, p. 236). In Red Flag Canal: a socio-ecological practice miracle from serendipity, through impossibility, to reality, a 2019 showcase article published in this journal, Wei-Ning Xiang presents a 1959 example of improvisation in socio-ecological practice (Xiang 2019c).

${ }^{2}$ Scholars often use Aristotelian phronesis and Platonian sophia to recognize Aristotle's contribution to the distinction and connection between the two virtues. For a brief, non-philosophical account on these two concepts, see Xiang (2016, pp. 53-55, 58); for a philosophical account, see Lawrence (2009, pp. 424-437).

3 This designation is necessary for two reasons. First, there are other interpretations of the flexible Lesbian rule in the early modern European literature, some are derogatory (DeCoursey 2011). Second, in the psychoanalytic literature, "lesbian rules" has a different connotation. It refers to "principles ... useful in thinking psychoanalytically about homosexuality... (and) [c]linical psychoanalysis uses..." (Magee and Miller 1997, p. 36; parentheses by the author).
}

\section{Inspirations we should act on}

\subsection{The approach of theorizing from good practice for good practice}

In this example, Aristotle first induced a general descriptive theory of practice (Aristotle's Lesbian rule) through observation and contemplation of craftsmen's efficacious and righteous practices- theorizing from good practice $^{4}$; he then extended the theory to the judicial field as he deduced that it would have the prescriptive power to inform and inspire judicial practitioners to be efficacious and righteous in their practice-theorizing for good practice. From such "a lively interplay ... between descriptive and prescriptive theory," as American legal scholar Roger Fisher calls it (Fisher 1983, p. 151), emerged an even more general theory of practice that remains true to the craftsmen and is useful-directly relevant, immediately actionable, and foreseeably efficacious (Xiang 2019a, p. 4, b, p. 9) -for the judicial practitioners. This effective approach to developing true and useful theories of practice has in fact been instrumental to several contemporary scholarly works on socio-ecological practice. ${ }^{5} \mathrm{We}$ should officially adopt it to our repertoire of socio-ecological practice research methodologies.

\subsection{The underlying premises}

Adopting the preceding approach requires our acceptance of its underlying premises. These premises would have served Aristotle in the above example and have been advocated by contemporary scholars on various occasions without acknowledging him as an intellectual forebear. Below is a compiled partial list of these premises with some of their advocates in parentheses. In reading it, one may benefit from the above example by using "craftsmen" in place of "practitioners" and "Aristotle" "academic theoretician."

1. Practitioners are theorists of their practice (Argyris and Schön 1974, pp. 7-8; Bolan 1980, pp. 271-272; Couclelis 1991, p. 383). A practitioners' theory of practice is a combination of beliefs, ideas, policies, procedures, and rationales about what to do and how to act in each concrete situation to achieve an intended consequence, and

\footnotetext{
${ }^{4}$ An instance of social practice is good when it is efficacious and righteous-works and works well [see footnotes 8 and 18 in Xiang (2019b, pp. 9 and 10)].

5 These include, but are not limited to, works by Bishop (2019), Forester (1999), Huang (2006), Innes (1995, 2017), Innes and Booher (2018), Liao (2019), Jim (2019), Liao et al. (2016), Lyle (1999), McHarg (1962, 1969, 2007), Scott et al. (2019), Susskind and Cruikshank (1987), Xiang (2019c), and Yang (2019).
} 
why (Argyris and Schön 1974, pp. 6-12; Bolan 1980, pp. 263-264; Couclelis 1991, pp. 382-383) ${ }^{6}$;

2. In each concrete situation, practitioners encounter the world as an irreducible totality and must think holistically and act pragmatically (Argyris and Schön 1974, pp. 7-8; Bolan 1980, p. 272; Mao 1937, pp. 296-297; Sandberg and Tsoukas 2011, pp. 341-343; Yan 2019, pp. 2-3);

3. As such, their theories of practice necessarily differ from theories of practice by academic theoreticians and definitely differ from theories of science, pure or applied (Argyris and Schön 1974, pp. 7-8; Bolan 1980, p. 263; Couclelis 1991, p. 383; Sandberg and Tsoukas 2011, pp. 338-339; Schön 2001, p. 191; Van de Ven 2007, pp. 3-6; Xiang 2017, pp. 2242-2243, 2019b, p. 9, d, p. 364; Yan 2019, pp. 1, 3-4);

4. Practitioners' theories of practice, when worked well in concrete situations, are inspirational and informative to those academic theoreticians who, like Aristotle, are interested in developing general theories of practiceacademics' theories of practice. ${ }^{7}$ They are therefore study-worthy (Couclelis 1991, p. 383; Forester 2017, pp. 283-284; Innes 1995, p. 183; Mao 1937, p. 299; Xiang 2019b, pp. 8-10, c);

5. Academics' theories of practice derived from practitioners' theories of practice describe what practitioners did in concrete situations and explain why; they may also prescribe how other practitioners in comparable situations should act and justify why. They are most likely to be true and useful because they have the capability of presenting truth and the power of informing and inspiring practitioners in other concrete situations to act efficaciously and righteously (Innes 1995, p. 183; Mao 1937, p. 300; Xiang 2019b, pp. 8-10, 2019c).

\footnotetext{
6 The "theory of practice" definition here also benefits from the "theory" definition 2a in The Merriam-Webster.com Dictionary, MerriamWebster Inc., https://www.merriam-webster.com/dictionary/theory. Accessed 20 December 2019.

${ }^{7}$ Merriam-Webster dictionary treats theoretician and theorist as synonyms and defines both as "a person who theorizes" (https://www. merriam-webster.com/dictionary/theoretician; https://www.merri am-webster.com/dictionary/theorist, accessed November 23, 2019). In this essay, however, these definitions are expanded to reflect a key nuance between the two words: theoretician refers to a scholar who constructs general theories of practice, while theorist is a practitioner who builds and uses theories of practice in concrete situations. The identification and deliberate use of this nuance are inspired by Couclelis' use of theoretician in Couclelis (1991, p. 383) and Bolan's use of theorist in Bolan (1980, p. 261). It is also interesting to note the statistical difference between the two nouns in their lookup popularity: theoretician is less popular-bottom $20 \%$ of words-than theorist-bottom $40 \%$ of words (https://www.merriam-webster.com/dictionary/theoretician; https://www.merriam-webster.com/dictionary/ theorist, accessed November 23, 2019).
}

Admittedly, we accept and uphold these premises not just for the "utilitarian" purpose of adopting an effective approach to theorizing. More importantly, they lay the very foundation for the pragmatic way of knowing in ecopracticology. [For the six strategies of the pragmatic way of knowing, see Xiang (2019b, pp. 10-11).]

\subsection{A role model}

The example renders a vivid image of the quintessential Aristotle as described by various Aristotle scholars (in parentheses): a scholar who builds theories based on direct observation of the real-world phenomena (Anagnostopoulos 2009, p. 5; Hammersley 2010, p. 396; North 2005, p. 91); a thinker who values both practical action and theoretical contemplation (Lear 2009, p. 388; North 2005, p. 93); and a writer who uses natural language to present the world of phenomena he observed and elucidates with the persuasive aspects of his observations (Keyt 2009, p. 32; North 2005, p. 93; Rapp 2009, p. 595). All these prodigious qualities remain invaluable in the twenty-first century and are highly desirable in our socio-ecological practice research. Aristotle is a role model we should follow with great reverence.

\section{An example of Smithian writing: in small words for big circles}

Between 1767 and 1773, Scottish philosopher and economist Adam Smith (1723-1790) settled in his hometown Kirkcaldy, Scotland, devoting much of the time to writing An Inquiry into the Nature and Causes of the Wealth of Nations (abbreviated as the Wealth of Nations, or WN) (Phillipson 2010, pp. 201-202). His ambition was to develop a book for a broad audience in political as well as intellectual circles "to facilitate the commercial policy in his own Great Britain" and "to contribute to the progress of humankind" (Evensky 2016, p. 68). This project of writing "for big circles" (Billig 2013, p. 15), according to Jerry Phillipson, a leading scholar of the Scottish Enlightenment, turned out to be a demanding undertaking (Phillipson 2010, p. 201). Among other challenges, explains Phillipson in his 2010 biography Adam Smith: An Enlightened Life (Ibid., pp. 216-217; parentheses by the author):

In writing the Wealth of Nations Smith faced the same problem he had encountered in writing the Theory of Moral Sentiments (first published in 1759): developing lectures originally designed for university students for a different sort of readership. ... The case of the Wealth of Nations was (nevertheless) more complicated(,) ... (in that) his political economy (the Wealth of Nations was written about) was deeply embedded 
in a system of moral philosophy, jurisprudence and politics about which most of his (nonacademic) readers knew nothing. The question was, how much of it did they need to know if they were to make sense of his political economy? Smith's answer was, not much. ${ }^{8}$

To keep this not much promise, Smith made every effort to write "in small words" for perspicuity (Billig 2013, p. 15). ${ }^{9}$ Perspicuity is the quality of being perspicuous-plain to the understanding because of clarity, elegance, precision, and simplicity of presentation. ${ }^{10} \mathrm{He}$, among other things, reduced the long, subtle lectures he had delivered at the University of Glasgow to "a series of strategically placed aphorisms and aperçus" (Phillipson 2010, p. 217); examined "carefully, and often painstakingly chosen historical examples" from Scotland and the colonial America (Ibid., pp. 227-228); employed figures of speech, primarily

\footnotetext{
${ }^{8}$ Between 1751 and 1763, Adam Smith was a professor of moral philosophy at the University of Glasgow, Scotland [see Chapters 6 and 8 in Phillipson (2010)], and lectured on ethics, politics, jurisprudence, natural theology, rhetoric, and belles-lettres (McKenna 2006, p. 16; Rae 1895, p. 43). During his tenure at Glasgow, he continued a pursuit he had begun in 1750 of the "very violent attack ... upon the whole commercial system of Great Britain" (Phillipson 2010, pp. 214 and 226); he shared many of these critical yet "piecemeal" ideas with students through lectures (Ibid., pp. 218-219; for the "piecemeal" quote, see p. 226). At the time of writing the Wealth of Nations (1767-1773), he was ready to relaunch the attack and bring it "to an intellectually and polemically devastating conclusion” (Ibid., p. 226). An integral part of this readiness was a general economic theory he had developed and refined in his last year at Glasgow (1763) and during his subsequent visits to France between 1764 and 1766 [Ibid., p. 219; see Chapter 9 in Phillipson (2010) for Smith's association with French economist François Quesnay (1694-1774) while in Paris]. He envisioned the Wealth of Nations "a book for statesmen, not students" (Phillipson 2010, p. 239)

9 This sentence is a paraphrase of the statement "Adam Smith was writing in small words for big circles" by British social psychologist Michael Billig in his 2013 book Learn to Write Badly: How to Succeed in the Social Sciences (p. 15). In making that statement, Billig meant that Smith wrote for perspicuity and "expected any educated reader to understand the ideas of (the) Wealth of Nations" (Ibid., p. 14; parenthesis by the author). The use of the term perspicuity in this context is attributed to English historian Edward Gibbon (17371794). Shortly after the publication of the Wealth of Nations on March 9, 1776, in a letter to Scottish philosopher Adam Ferguson (1723-1816) dated April 1, 1776, Gibbon offered the following generous praise: "What an excellent work is that with which our common friend Mr. Adam Smith has enriched the public! An extensive science in a single book, and the most profound ideas expressed in the most perspicuous language." [cited in Rae (1895, p. 287), italic by the author] Gibbon's own book The History of the Decline and Fall of the Roman Empire was first published in February 1776, only a month before the Wealth of Nations (McCrum 2017). The publication of these two books made 1776 an annus mirabilis for English and American prose (Ibid.)

10 "Perspicuous." The Merriam-Webster.com Dictionary, MerriamWebster Inc., https://www.merriam-webster.com/dictionary/perspicuous. Accessed January 10th, 2020
}

metaphors plus a few similes, "to add meaning and interest in his sentences" (Kennedy 2017, p. 61); and used "wellturned phrases" (Heilbroner 1999, p. 52) and "non-technical words that he thought all educated readers would understand" (Billig 2013, p. 15).

His hard work paid off nicely. The first edition of the Wealth of Nations was sold out in 6 months (Rae 1895, p. 285) and "immediately acquired a significant readership in political and intellectual circles in Edinburgh, London and Paris" (Phillipson 2010, p. 1). The then British Prime Minister, Lord North, regarded the book as "a mine of suggestions" for "fresh, convenient and easy means of increasing the revenue" and benefitted from the book in preparing the budgets for the years 1777 and 1778 (Rae 1895, p. 320). Many members in the British governments knew and admired the book and recognized its public value (Rae 1895, p. 321; Phillipson 2010, p. 267). Various statesmen turned to Smith for advice on issues pertaining to the war with the colonial America and the trade with Ireland (McKenna 2006, p. 21). The book itself was recognized as a masterpiece of "the most profound ideas expressed in the most perspicuous language" [Gibbon 1776, cited in Rae (1895, p. 287); see also footnote 9 in this essay]. It ultimately becomes his magnum opus (Heilbroner 1986, p. 149) and, more importantly, a classic book on political economy with lasting impacts (Ross 2010, pp. 445-451). ${ }^{11}$

\section{Inspirations we should act on}

\subsection{The strategy of writing in small words for big circles}

In this example, Adam Smith meticulously used a variety of "small words" techniques in his book writing for a broad audience in "big circles": aphorisms, aperçus, examples, figures of speech, plain language, and non-technical words. ${ }^{12}$

\footnotetext{
${ }^{11}$ In his 2010 book The Life of Adam Smith (second edition), Scottish-Canadian biographer Ian Ross offers a succinct account on the book's many enduring impacts (pp. 445-451). He also illustrates how Smithian ideas influenced world leaders in their policy making, including Ronald Reagan, Margaret Thatcher, John Major, Tony Blair, Gordon Brown, and Barack Obama (Ibid., pp. 481-490). Another aspect of the book's lasting impact is found in Google Scholar-the more recent English language editions $(1960,2010)$ together have been cited 54,471 time since their publications (https://scholar.google.com/scholar_lookup?title=An+Inqui ry+into + the +Nature+and +Causes + of + the + Wealth + of + Natio ns\&author $=$ Adam + Smith\&publication_year $=1776$, accessed January 10th, 2020)

12 For in-depth discussions about these and other "small words" techniques Adam Smith used in writing the Wealth of Nations, see Heilbroner (1986, pp. 149-157), Kennedy (2017, pp. 35-78), and Phillipson (2010, pp. 214-238)
} 
The outcome was brilliant, influence significant. We should follow this effective strategy in fulfilling our commitment to writing for a broad audience in and beyond the socioecological practice research community. ${ }^{13}$

\subsection{A perspicuous writing style}

According to American economist and historian Robert Heilbroner, a commonplace about the Wealth of Nations is that it "is not a wholly original book, but it is unquestionably a masterpiece" (Heilbroner 1999, p. 51). "There is a long line of observers before Smith who have approached his understanding of the world: Locke, Steuart, Mandeville, Petty, Cantillon, Turgot, not to mention Quesnay and Hume..." (Ibid.) ${ }^{14}$ No wonder many Smith's contemporaries were so surprised with the immediate success of the book, including his best friend and mentor David Hume (McKenna 2006, p. 20; Phillipson 2010, p. 1).

But then, what had made "very popular" such an unoriginal book that "contained very little which was particularly new"? (McKenna 2006, p. 20) The perspicuous style of Smith's writing stands out from the crowd, asserts American rhetorician Stephen McKenna in his 2006 book Adam Smith: The Rhetoric of Propriety. "[Q]uite likely a significant cause of this surprising success (of the Wealth of Nations) was the style of Smith's writing, which was, like that of his previous book (the Theory of Moral Sentiments), widely remarked to be lucid and compelling" (McKenna 2006, p. 20; parentheses by the author).

To be sure, not only did his perspicuous writing style help boost the book's popularity in big circles, but it contributed substantially to the making of this masterpiece. Commends Robert Heilbroner in his 1999 book The Worldly Philosophers: The Lives, Times, and Ideas of the Great Economic Thinkers, "[F]or all its weightiness, the text is shot through with insights, observations, and well-turned phrases that imbue this great lecture with life" (Heilbroner 1999, p. 52). With this perspicuous writing style, "where others had fished here and there, Smith spread his net wide; where others had clarified this and that issue, Smith illuminated the entire landscape" (Ibid., p. 51). His writing style as such "become(s) an essential part of the language of (his) political

\footnotetext{
${ }^{13}$ For the effectiveness of this strategy in the practice research literature, a comparison is telling between two treatises on theories of practice. Evidently, On practice (Mao 1937) is written in small words for big circles, while The Logic of Practice (Bourdieu 1990) is not.

14 John Locke (1632-1704) was an English philosopher, James Steuart (1707-1780) Scottish economist, Bernard de Mandeville (1670-1733) Dutch philosopher, William Petty (1623-1687) English economist, Richard Cantillon (1680 s-1734) Irish-French economist, Anne-Robert-Jacques Turgot (1727-1781) and François Quesnay (1694-1774) French economists, and David Hume (1711-1776) Scottish philosopher.
}

economy itself" (Phillipson 2010, p. 217; parentheses by the author). Many well-turned phrases or passages are so striking and memorable that they have become iconic and immortal ever since. The "invisible hand" of market and the famous passage "It is not from the benevolence of the butcher, the brewer, or the baker that we expect our dinner, but from their regard to their own interest" are but two most famous examples. ${ }^{15}$

Perspicuous writing matters-it can make a huge difference. We should adopt this style of writing without question.

\subsection{A careful and diligent writer}

Style is the man, one's chosen style of writing reflects one's essential characteristics. 16 "Adam Smith was a very careful writer and not given to sloppiness in his written composition," writes British economist Gavin Kennedy in his 2017 book An Authentic Account of Adam Smith (p. 44).

"For Smith, perspicuity was the gold standard" for all his works (Ibid., p. 43). "To meet his own high standards, he took the trouble to compose and recompose whatever he wrote" (Ibid., p. 39). In a letter dated March 18, 1788, writes Smith, "I am a slow, very slow workman, who do and undo everything I write at least half a dozen times before I can be tolerably pleased with it" (cited in Kennedy 2017, p. 39; McKenna 2006, p. 23) ${ }^{17}$ In pursuit of greater perspicuity, he kept revising his two major works diligently during his lifetime and produced substantially revised and expanded editions of the Wealth of Nations (5 editions in 12 years) and the Theory of Moral Sentiments (6 editions in 31 years) (Kennedy 2017, pp. 11, 60, 62; McKenna 2006, p. 23). ${ }^{18}$

\footnotetext{
15 For a brief selection of aphorisms and famous passages from the Wealth of Nations, see Heilbroner (1986, pp. 321-324); for a thoughtful selection of annotated figures of speech (metaphors and a few similes), see Kennedy (2017, pp. 69-77).

16 "Style is the man" (The Oxford Dictionary of Phrase and Fable, https://www.encyclopedia.com/humanities/dictionaries-thesauruse s-pictures-and-press-releases/style-man, accessed January 18, 2020). It resonates to the Chinese proverb 文如其人 (https://www.zdic.net/ hans/文如其人, accessed January 18, 2020) and the converse 人如其 文.

17 This was in an age of handwriting - all manuscripts had to be handwritten. It is therefore anyone's guess how much time it would have taken Smith to write his manuscript just one time.

${ }^{18}$ In his continuous, successful pursuit of perspicuity, Smith benefitted from his own practical experience. According to John Rae (18451915), a Scottish biographer whose 1895 biography Life of Adam Smith is widely regarded as a major Smith reference (Kennedy 2017, p. 1), in November 1777, Smith was appointed to the five-person Board of Customs in Scotland "as an express recognition on the part of the (British) Premier (Lord North) of the public value of Smith's work" (Rae 1895, p. 321; parentheses by the author). He attended his official work "with uncommon diligence" (Ibid., p. 330) and "found it useful to his economic studies" (Ibid., p. 332). From this practical experience, he discerned "how essential practical knowledge was to the thorough understanding of political subjects." (Ibid.) This is evi-
} 
To become a careful and diligent writer who brings writing to life, we should follow his example.

\section{Are we ready to act?}

There is nothing as inspirational as a good example. ${ }^{19}$ To fulfill our commitments to developing true and useful theories of socio-ecological practice and writing for a broad audience, I believe that we should act on the inspirations from the classic examples of Aristotelian theorizing and Smithian writing - theorize from good practice for good practice and write in small words for big circles.

But are we ready to act?

For many of us, to act on these inspirations requires not just a change in ways of knowing and writing, which admittedly is a huge undertaking in its own right; it also demands a personal reorientation in academic life. Consider the cases of Aristotle and Adam Smith. They lived in an academic world where, as British historian Paul Johnson describes in his 1992 book The Birth of the Modern: World Society 1815-1830, "[p]hysics and chemistry, science and engineering, literature and philosophy, art and industrial design, theory and practice-all constituted a continuum of knowledge and skill, within which men roamed freely. The notion of separate, compartmentalized 'disciplines,' later imposed by universities, did not yet exist" (Johnson 1992, p. 543). Like many great minds in their times, both were solitary scholars of self-directed scholarship, in that they pursued intellectual interests where the interests took them and communicated their ideas as widely as possible in both speaking and writing (Billig 2013, p. 15; Hutchison 1976, pp. 511-512; Taleb 2012 , p. 227). The academic world we live in today is so much different: among other things, disciplinary divides seem insuperable, research and publications are being mass produced, we are nurtured "to write badly" or otherwise punished (Billig 2013, pp. 12-39 and 40-66; Pinker 2014; Robinson 2017, 2019), and scholarly journals are so specialized that " $[\mathrm{t}]$ he words (in the articles published) have become longer and the circles, in which they circulate, have become smaller" (Billig 2013, p. 15; parentheses by the author). For some of us, therefore, to follow the examples

\footnotetext{
Footnote 18 (continued)

dent in the third edition of the Wealth of Nations (first published after his settlement in the Customs) in which most of the additions and corrections are connected to that branch of the public service (Ibid., p. 333).

19 This is because, as Michael Billig puts it eloquently in his 2019 book More Examples, Less Theory: Historical Studies of Writing Psychology, "[w]hen (good) examples are examined closely, they can provide a royal route to understanding general processes" (Billig 2019, p. 257; parentheses by the author).
}

set by Aristotle and Adam Smith means to step out of our comfort zone which we have worked so hard to get into; for others, especially younger generations, it means to take an unfamiliar detour from a direct, established course. Are we still ready to act?

\section{Yes, we are ready!}

There are two apparent reasons.

\subsection{We have good examples to follow}

Of those contemporary scholars and scholar-practitioners whose works contributed to the scholarship in ecopracticology [see the partial list in footnote 5; and in Xiang (2019b, p. 9)], some have reoriented and even reinvented themselves one or multiple times on their academic journeys. ${ }^{20}$ In doing so, they in fact followed in the footsteps of many intellectual ancestors who had done exactly the same: American pragmatist William James (1842-1910), German-American design scholar Horst Rittel (1930-1990), American planning scholar Melvin Webber (1920-2006), and systems scientist West Churchman (1913-2004), to name just a few. ${ }^{21}$ Collectively, these scholars set powerful examples for us to act boldly yet thoughtfully on the inspirations from the classic examples of Aristotelian theorizing and Smithian writing.

\subsection{We have a suitable journal to publish in}

Socio-Ecological Practice Research (SEPR) is the home journal of ecopracticology (Xiang 2019b, p. 12). As

\footnotetext{
${ }^{20}$ One of them is American planning scholar Judy Innes, a professor emeritus of city and regional planning at the University of California at Berkeley, USA. For a personal reflection on reorientations in her academic life, see Innes (1995); for an intellectual autobiography in which she offers a detailed narrative of her scholarly pursuits and career path, see Innes (2017).

${ }^{21}$ Michael Billig describes William James as a "restless roamer" who liked to roam wherever his curiosity took him (2013, p. 15). "At Harvard (University), James belonged successively to the departments of medicine, psychology and philosophy before finally leaving the university to work independently" (Ibid., pp. 15-16; parenthesis by the author). Horst Rittel, Melvin Webber, and West Churchman are known for their seminal work on wicked problems in planning and design (Churchman 1967; Rittel and Webber 1973; for a brief review of the enduring significance of their work, see Xiang 2013). This influential work is a hallmark of personal reinvention and brainchild of collective reflection. As American design scholar Richard Buchanan puts it, they are scholars who are "initially influenced by neo-positivist ideas who, when confronted with the actual processes of practical reasoning in concrete circumstances, sought to develop a new approach (to planning and design research)" (Buchanan 1992, p. 16 ; parenthesis by the author).
} 
a one-of-its-kind transdisciplinary journal on practice research, SEPR celebrates and cultivates the Aristotelian-Smithian type of scholarship. This is evident in the following five virtues SEPR articles are expected to possess (Xiang 2019a, p. 4) — the virtues are much in line with those showcased in the two classic examples:

1. attentiveness to the dual ambition of producing new knowledge and improving socio-ecological practice;

2. interest in the usefulness of knowledge;

3. commitment to scholarly rigor;

4. writing with style, accuracy, brevity, and clarity;

5. the quality of international appeal.

Since its debut in 2019, SEPR has been receiving strong support from a growing community of international authors and readers across a wide range of scholarly and practical fields. This is apparent in the articles it published to date and shown in the numbers of article downloads and citations (https://www.springer.com/journal/42532).

In conclusion, the path has been paved; to fulfill our commitments, let's march on and act together under the banner

\section{from good practice for good practice we theorize; in small words for big circles we write.}

Acknowledgements I am indebted to the following individuals who provided valuable assistance during the preparation of this article (in alphabetic order): Ying Chen (Tongji University, Shanghai, China), Matthew DeCoursey (Education University of Hong Kong, China), Robert Hayes (Harvard Business School, USA), Reese Manceaux and Brad Spry (both with Atkins Library, University of North Carolina at Charlotte, USA), Barry Schwartz (Swarthmore College, USA), and Jie Zeng (Chinese University of Geosciences, Wuhan, China).

\section{References}

Anagnostopoulos G (2009) Aristotle's life. In: Anagnostopoulos G (ed) A companion to Aristotle. Wiley-Blackwell, Chichester, pp 3-13

Argyris C, Schön DA (1974) Theory in practice: increasing professional effectiveness. Jossey-Bass Publishers, San Francisco

Aristotle (1999) Nicomachean ethics. Translated with introduction, notes, and glossary, by Terence Irwin, 2nd edn. Hackett Publishing Company, Indianapolis

Billig M (2013) Learn to write badly: how to succeed in the social sciences. Cambridge University Press, Cambridge

Billig M (2019) More examples, less theory: historical studies of writing psychology. Cambridge University Press, Cambridge

Bishop I (2019) Evidence synthesis in landscape aesthetics: an honourable endeavour yet insufficient applicable knowledge. Socio-Ecol Pract Res 1(2):93-108. https://doi.org/10.1007/s42532-019-00011-9

Bolan RS (1980) The practitioner as theorist: the phenomenology of the professional episode. J Am Plan Assoc 46(3):261-274. https ://doi.org/10.1080/01944368008977042
Bourdieu P (1990) The logic of practice (Translated by Richard Nice). Stanford University Press, Stanford

Buchanan R (1992) Wicked problems in design thinking. Des Issues $8(2): 5-21$

Churchman CW (1967) Wicked problems. Manag Sci 14(4):B141-B142

Couclelis H (1991) There is nothing as theoretical as good practice. Environ Plan 18:379-384

DeCoursey M (2011) Three interpretations of the Lesbian rule in early modern Europe. Notes Queries 58(2):293-295

Evensky J (2016) The wealth of nations. In: Hanley RP (ed) Adam Smith: his life, thought, and legacy. Princeton University Press, Princeton, pp 67-88

Fisher R (1983) Negotiating power. Am Behav Sci 27(2):149-166

Forester J (1999) The deliberative practitioner: encouraging participatory planning processes. The MIT Press, Boston

Forester J (2017) On the evolution of a critical pragmatism. In: Haselsberger B (ed) Encounters in planning thought: 16 autobiographical essays from key thinkers in planning. Routledge, New York, pp 280-296

Forester J (2019) Five generations of theory-practice tensions: enriching socio-ecological practice research. Socio-Ecol Pract Res. https ://doi.org/10.1007/s42532-019-00033-3

Hammersley M (2010) Aristotelian or Galileian? On a puzzle about the philosophical sources of analytic induction. J Theory Soc Behav 40(4):393-409

Heilbroner RL (1986) The essential Adam Smith. Norton, New York

Heilbroner RL (1999) The worldly philosophers: the lives, times, and ideas of the great economic thinkers. Simon \& Schuster, New York

Huang G (2006) Theory of mountainurbanology. China Architecture Publishing \& Media Co., Beijing (in Chinese) [黄光宇 (2006) 《山地城市学原理》, 中国建筑工业出版社, 北京]

Hutchison T (1976) Adam Smith and the wealth of nations. J Law Econ 19(3):507-528

Innes JE (1995) Planning theory's emerging paradigm: communicative action and interactive practice. J Plan Educ Res 14:183-189

Innes JE (2017) From informing policy to collaborating rationally. An intellectual autobiography. In: Haselsberger B (ed) Encounters in planning thought: 16 autobiographical essays from key thinkers in planning. Routledge, New York, pp 145-164

Innes JE, Booher DE (2018) Planning with complexity: an introduction to collaborative rationality for public policy, 2nd edn. Routledge, London

James H (2016) Hans-Werner Sinn, Cassandra and the Aristotle's Lesbian rule. CESifo Forum 17:18-19

Jim CY (2019) Resolving intractable soil constraints in urban forestry through research-practice synergy. Socio-Ecol Pract Res 1(1):4153. https://doi.org/10.1007/s42532-018-00005-z

Johnson P (1992) The birth of the modern: world society 1815-1830. Harper Perennial, New York

Kennedy G (2017) An authentic account of Adam Smith. Palgrave Macmillan, Cham

Keyt D (2009) Deductive logic. In: Anagnostopoulos G (ed) A companion to Aristotle. Wiley-Blackwell, Chichester, pp 31-50

Lawrence G (2009) Human excellence in character and intellect. In: Anagnostopoulos G (ed) A companion to Aristotle. Wiley-Blackwell, Chichester, pp 419-441

Lear GR (2009) Happiness and the structure of ends. In: Anagnostopoulos G (ed) A companion to Aristotle. Wiley-Blackwell, Chichester, pp 387-403

Liao KH (2019) The socio-ecological practice of building blue-green infrastructure in high-density cities: what does the ABC Waters Program in Singapore tell us? Socio-Ecol Pract Res. https://doi. org/10.1007/s42532-019-00009-3 
Liao K-H, Le TA, Nguyen KV (2016) Urban design principles for flood resilience: learning from the ecological wisdom of living with floods in the Vietnamese Mekong Delta. Lands Urban Plan 155:69-78

Lyle JT (1999) Design for human ecosystems: landscape, land use, and natural resources. Island Press, Washington

Magee M, Miller D (1997) Lesbian lives: psychoanalytic narratives old and new. The Analytic Press, Hillsdale

Mao T-T (1937) On practice: on the relation between knowledge and practice, between knowing and doing. In: Selected works of Mao Tse-Tung, vol 1. Foreign Language Press, Beijing, pp 295-309 [This is a translation of the below essay in the first Chinese edition of Mao's book (1951)]

McCrum R (2017) 100 best nonfiction books: no 84-the wealth of nations by Adam Smith (1776): blending history, philosophy, psychology, and sociology, the Scottish intellectual single-handedly invented modern political economy. The Guardian, Mon 11 Sep 2017 00.45 EDT Last modified on Wed 21 Mar 2018 19.50 EDT. https://www.theguardian.com/books/2017/sep/11/100-best-nonfi ction-books-84-the-wealth-of-nations-by-adam-smith. Accessed 15 Dec 2019

McHarg IL (1962) The ecology of the city. J Archit Educ 17(2):101-103

McHarg IL (1969) Design with nature. Doubleday/Natural History Press, New York

McHarg IL (2007) The theory of creative fitting. In: Margulis L, Corner J, Hawthorne B (eds) Ian McHarg: conversations with students: dwelling in nature. Princeton Architectural Press, New York, pp 19-61

McKenna SJ (2006) Adam Smith: the rhetoric of propriety. Southern Illinois University Press, Carbondale

North J (2005) Aristotle's empiricism. Early Sci Med 10(1):91-97

Nussbaum M (1990) The discernment of perception: an Aristotelian conception of private and public rationality. In: Nussbaum M (ed) Love's knowledge: essays on philosophy and literature. Oxford University Press, New York, pp 54-105

Phillipson N (2010) Adam Smith: an enlightened life. Yale University Press, New Haven

Pinker S (2014) Why academics stink at writing. Chronicle of Higher Education, September 26

Rae J (1895) Life of Adam Smith. Macmillan, London [Online Library of Liberty. https://oll.libertyfund.org/titles/1411. Downloaded on 15 Dec 2019]

Rapp C (2009) The nature and goals of rhetoric. In: Anagnostopoulos G (ed) A companion to Aristotle. Wiley-Blackwell, Chichester, pp 579-596

Rittel HWJ, Webber MM (1973) Dilemmas in a general theory of planning. Policy Sci 4:155-169

Robinson NJ (2017) Academic language and the problem of meaninglessness. Current Affairs: A Magazine of Politics and Culture. https://www.currentaffairs.org/2017/07/academic-language-andthe-problem-of-meaninglessness. Accessed 8 Jan 2020

Robinson NJ (2019) Academics cannot evade their public responsibilities. Current Affairs: A Magazine of Politics and Culture. https ://www.currentaffairs.org/2019/09/academics-cannot-evade-their -public-responsibilities. Accessed 8 Jan 2020

Ross IS (2010) The life of Adam Smith, 2nd edn. Oxford University Press, Oxford

Sandberg J, Tsoukas H (2011) Grasping the logic of practice: theorizing through practical rationality. Acad Manag Rev 36(2):338-360
Schön DA (2001) Chapter 13: The crisis of professional knowledge and the pursuit of an epistemology of practice. Counterpoints 166:183-207

Schwartz B, Sharpe K (2010) Practical wisdom: the right way to do the right thing. Riverhead Books, New York

Scott D, Bogunovich D, Bradbury M (2019) Designing Aotearoa New Zealand with nature: landscape regeneration of Western Waiheke Island. Socio-Ecol Pract Res 1(3-4):265-281. https:// doi.org/10.1007/s42532-019-00034-2

Susskind L, Cruikshank J (1987) Breaking the impasse: consensual approaches to resolving public disputes. Basic Books, New York

Taleb NN (2012) Antifragile: things that gain from disorder. Random House, New York

Van de Ven AH (2007) Engaged scholarship: a guide for organizational and social research. The Oxford University Press, Oxford

Xiang W-N (2013) Working with wicked problems in socio-ecological systems: awareness, acceptance, and adaptation. Landsc Urban Plan 110(1):1-4

Xiang W-N (2016) Ecophronesis: the ecological practical wisdom for and from ecological practice. Landsc Urban Plan 155:53-60

Xiang W-N (2017) Pasteur's quadrant: an appealing ecophronetic alternative to the prevalent Bohr's quadrant in ecosystem services research. Landsc Ecol 32(12):2241-2247. https://doi.org/10.1007/ s10980-017-0583-y

Xiang W-N (2019a) Socio-ecological practice research (SEPR): what does the journal have to offer? Socio-Ecol Pract Res 1(1):1-5. https://doi.org/10.1007/s42532-018-0001-y

Xiang W-N (2019b) Ecopracticology: the study of socio-ecological practice. Socio-Ecol Pract Res 1(1):7-14. https://doi.org/10.1007/ s42532-019-00006-6

Xiang W-N (2019c) The Red Flag Canal: a socio-ecological practice miracle from serendipity, through impossibility, to reality. SocioEcol Pract Res. https://doi.org/10.1007/s42532-019-00037-z

Xiang W-N (2019d) Why did history vote many times in his favor? Four reasons for McHarg's achievements in socio-ecological practice research. Socio-Ecol Pract Res 1(3-4):359-369. https://doi. org/10.1007/s42532-019-00023-5

Yan W (2019) The logic of ecological practice. Urban Plan Int 34(3):1-8 (in Chinese). https://doi.org/10.22217/upi.2019.140 [颜文涛. 生态实践的逻辑. 国际城市规划, 2019, 34(3):1-8]

Yang B (2019) Landscape performance: Ian McHarg's ecological planning in the Woodlands, Texas. Routledge, London

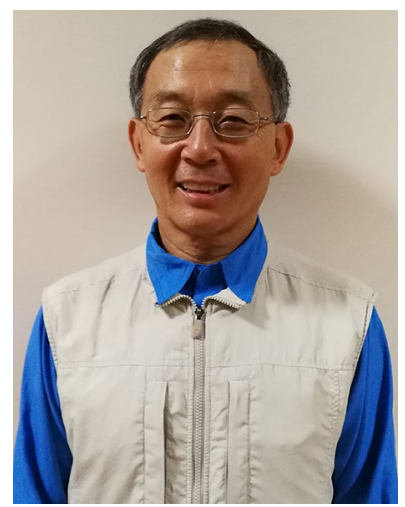

Wei-Ning Xiang is a Professor of Geography and Earth Sciences at the University of North Carolina at Charlotte, USA (1990-present); a Visiting Fellow of Ecophronetic Practice Research at Tongji University, Shanghai, China; the former co-editor-inchief of Landscape and Urban Planning (2011-2018); he is the founding editor-in-chief of Socio-Ecological Practice Research (SEPR). 